Hal $21-29$

\title{
PENGARUH METODE PEMBELAJARAN PROBLEM SOLVING TERHADAP PEMECAHAN MASALAH MATEMATIKA SISWA KELAS XI SMA MUHAMMADIYAH-10 RANTAUPRAPAT
}

\author{
Jayanti Ratnasari ${ }^{1}$, Irmayanti ${ }^{2}$, Eva Julyanti ${ }^{3}$ \\ ${ }^{1}$ Mahasiswa Program Studi Pendidikan Matematika STKIP Labuhanbatu \\ ${ }^{2}$ Dosen Program Studi Pendidikan Matematika STKIP Labuhanbatu \\ ${ }^{3}$ Dosen Program Studi Pendidikan Matematika STKIP Labuhanbatu \\ STKIP Labuhanbatu,JIn. SM. Raja No. 126A, KM, 3.5 Aek Tapa, Rantauprapat \\ Email: jayantiratna780@gmail.com
}

Diterima (April 2018) dan disetujui (Mei 2018)

\begin{abstract}
ABSTRAK
Penelitian ini bertujuan: (1)untuk mengetahui pengaruh metode pembelajaran problem solving terhadap kemampuan pemecahan masalah matematika kelas XI SMA Muhammadiyah-10 Rantauprapat, (2)untuk mengetahui proses jawaban siswa dengan metode problem solving terhadap kemampuan pemecahan masalah matematika siswa kelas XI SMA Muhammadiyah-10 Rantauprapat. Jenis penelitian ini adalah quasi eksperimen dengan populasi seluruh siswa kelas XI SMA Muhammadiyah 10 Rantauprapat yang terdiri dari 2 kelas dengan jumlah seluruh populasi adalah 49 siswa. Sampel penelitian diambil kelas XI-IPA yang berjumlah 28 siswa, dengan teknik pengambilan sampel menggunakan purposive sampling (sampling pertimbangan). Instrument yang digunakan dalam penelitian ini adalah tes kemampuan pemecahan masalah matematika siswa dalam bentuk essay sebanyak 4 soal. Data rata-rata pre-test kelas eksperimen adalah 33,5 dengan kriteria sedang dan memiliki standart deviasi sebesar 4,0778. Setelah diberikan perlakuan dengan menggunakan metode problem solving diperoleh rata-rata post-test pada kelas eksperimen sebesar 41,60 dengan kriteria tinggi dan memiliki standart deviasi sebesar 3,235. Pada hasil pengujian hipotesis dengan menggunakan uji t diperoleh - $t_{\text {tabel }} \geq t_{\text {hitung }} \leq t_{\text {tabel }}$ yaitu $-2,0518>-16,492<2,0518$ pada taraf signifikan $\alpha=0,05 \mathrm{dan} d \mathrm{k}=27$. Dengan demikian Ho ditolak yang berarti terdapat pengaruh kemampuan pemecahan masalah matematika yang menggunakan metode pembelajaran Problem solving di kelas eksperimen yang signifikan antara pre-test maupun post-test. Berdasarkan proses jawaban siswa diperoleh skor terendah pre-test adalah 7 dan skor tertinggi pre-test adalah 10. Setelah diberikan perlakuan metode pembelajaran problem solving diperoleh skor terendah post-test adalah 8 dan skor tertinggi post-test adalah 13.
\end{abstract}

Kata Kunci: Metode Pembelajaran Problem Solving, Kemampuan Pemechan Masalah Matematika. 


\section{PENDAHULUAN}

Dalam mencapai mutu pendidikan di Indonesia yang baik, diperlukan suatu proses berpikir dan bernalar siswa dalam pembelajaran matematika. Hal ini sesuai National Council of Teachers of Mathematics/NCTM(Ainun,2015)mengemu kakan bahwa terdapat lima proses standar bagi siswa dalam memperoleh dan menggunakan pengetahuan matematis yaitu: pemecahan masalah, penalaran dan pembuktian (reasoning and proof), komunikasi(communication), koneksi (connection), dan representasi (representation). Proses penalaran, pengambilan keputusan, dan pemecahan masalah merupakan aktivitas mental yang membentuk inti berpikir. Kemampuan penalaran matematis merupakan salah satu bagian yang utama yang hendak dicapai dalam tujuan pembelajaran matematika. Hal ini berarti penalaran matematika adalah fondasi untuk mendapatkan atau menkonstruk pengetahuan matematika. Dengan demikian berarti guru di sekolah dasar dan menengah harus mengembangkan kemampuan penalaran siswa dalam pembelajaran matematika.

Berdasarkan hasil observasi awal pada hari kamis tanggal 13 April 2017 peneliti melakukan wawancara terhadap guru mata pelajaran matematika ibu Zubaidah S.Pd, dari hasil wawancara diperoleh informasi bahwa masih kurangnya kemampuan penalaran siswa kelas VIII sebagian besar siswa mengalami kesulitan dalam proses penalaran menyelesaikan soal cerita. Menurut ibu Zubaidah S.Pd selaku guru matematika disekolah SMP Negeri 2 Na. IX-X Sumberjo , kesalahan siswa disebabkan oleh banyaknya siswa yang belum memahami maksud dari soal yang diberikan sehingga siswa kesulitan dalam menyelesaikan soal. Lebih lanjut ibu Zubaidah S.Pd mengungkapkan bahwa pada umumnya tingkat kemampuan penalaran siswa dalam menyelesaikan soal cerita memang masih relatif rendah disekolah SMP Negeri $2 \mathrm{Na}$. IX-X Sumberjo. Kesulitan yang dialami siswa tersebut, disebabkan oleh faktor model pembelajaran yang digunakan kurang membangun kemampuan penalaran siswa, proses belajar mengajar hanya terpusat pada guru yaitu guru menjelaskan, siswa mendengarkan sambil mencatat, guru bertanya, murid menjawab, siswa mengerjakan soal-soal latihan. maka diperlukan suatu alternatif model pembelajaran yang dapat membantu kemampuan penalaran siswa dalam menyelesaikan soal-soal yang mengacu pada kehidupan nyata. Adapun salah satu model pembelajaran yang dapat digunakan adalah model pembelajaran problem posing.

Problem Posing merupakan suatu model pembelajaran yang menekankan pada kegiatan merumuskan masalah untuk membina siswa sehingga dapat meningkatkan kemampuan penalaran dalam menyelesaikan masalah. Problem Posing merupakan pembelajaran dimana siswa berperan aktif untuk membentuk soal dan siswa tersebut diharapkan dapat menyelesaikan soal yang diberikan. Model pembelajaran ini dapat mengubah cara berfikir siswa awalnya pasif menjadi lebih akif. Problem Posing dapat memfasilitasi pengembangan penalaran pada siswa agar dapat mengembangkan kemampuan dan kesukaan pada pembelajaran matematika.

\section{Pengertian Kemampuan Penalaran Matematis}

Penalaran berasal dari kata nalar yang mempunyai arti pertimbangan tentang baik buruk, kekuatan pikir atau aktivitas yang memungkinkan seseorang berpikir logis. Sedangkan penalaran yaitu cara menggunakan nalar atau proses mental dalam dalam mengembangkan pikiran dari beberapa fakta atau prinsip. Math Glossary (Priatna 2013) menyatakan definisi penalaran matematis adalah berpikir mengenai permasalahan-permasalahan matematika secara logis untuk memperoleh penyelesaian dan bahwa penalaran matematis mensyaratkan kemampuan untuk memilah apa yang penting dan tidak penting dalam menyelesaikan sebuah permasalahan dan untuk menjelaskan atau memberikan alasan atas sebuah penyelesaian.

\section{Pengertian Problem Posing}

Problem posing merupakan istilah dalam bahasa inggris yaitu dari kata "problem" artinya masalah, soal atau persoalan dan kata "pose" yang artinya 
mengajukan. Jadi problem posing bisa diartikan sebagai pengajuan masalah. Problem Posing merupakan suatu model pembelajaran yang menekankan pada kegiatan pembentukan/merumuskan masalah untuk membina siswa sehingga dapat meningkatkan kemampuan penalaranya dalam menyelesaikan masalah. The Curriculum an Evaluation Standard for School Mathematics merumuskan secara eksplisit bahwa siswa harus mempunyai pengalaman mengenal dan memformulasikan masalah (soal) mereka sendiri.

\section{METODOLOGI PENELITIAN}

Penelitian ini dilaksanakan di SMP Negeri $2 \mathrm{Na}$. IX-X Sumberjo yang berlokasi di Desa Sei Raja, Dusun Sumberjo, Kecamatan Na. IX-X, Kabupaten Labuhanbatu Utara. Penelitian dilaksanakan pada semester ganjil tahun ajaran

\begin{tabular}{|c|c|c|c|}
\hline Kelompok & Tes Awal & Perlakuan & Tes Akhir \\
\hline Eksperimen & $\mathrm{O}_{1}$ & $\mathrm{X}$ & $\mathrm{O}_{2}$ \\
\hline
\end{tabular}

Keterangan:
2017/2018 pada bulan Juli. Populasi dalam penelitian ini adalah seluruh siswa kelas VIII SMP Negeri 2 NA. IX-X Sumberjo Tahun Pembelajaran 2017/2018, yang terdiri dari 3 kelas dengan jumlah siswa 93 orang. Teknik pengambilan sampel yang digunakan dalam penelitian ini adalah Cluster Random Sampling (pemilihan sampel cara kelompok). Sampel yang digunakan dalam penelitian ini adalah siswa kelas $\mathrm{VIII}^{3}$ yang berjumlah 28 siswa.

Penelitian ini menggunakan jenis penelitian Kuantitatif dan metode yang digunakan yaitu metode quasi-eksperiment. Desain penelitian yang digunakan One Group Pretest-posttes. Dimana, agar hasil perlakuan dapat diketahui dengan akurat maka kelompok eksperimen di beri perlakuan awal (pretest) kemudian di beri perlakuan akhir (posttest).

Adapun desain penelitian, Sugiyono (2008:75) sebagai berikut:

\section{$X$ : Perlakuan menggunakan Model Pembelajaran ProblemPosing \\ $\mathrm{O}_{1}$ : Pretest}

$\mathrm{O}_{2}$ : Posttest

Untuk mengetahui sejauh mana pengaruh Model Pembelajaran Problem Posing terhadap kemampuan penalaran matematis siswa maka instrumen yang digunakan dalam penelitian ini berupa tes. Tes tertulis yang diberikan yaitu berupa (pre-test) berbentuk 5 soal uraian dan (post-test) berbentuk 5 soal uraian. Sebelum diujikan, peneliti melakukan uji coba instrument terlebih dahulu. Uji coba instrument dilakukan dengan meminta pendapat para ahli dan melakukan validasi konstruk dengan memberikan 10 soal uraian kepada siswa yang terdiri 20 orang.

Untuk selanjutnya pengelolaan data diawali dengan menghitung uji prasyarat yaitu uji normalitas dan uji homogenitas, kemudian dilakukan uji-t untuk menguji hipotesis yang disesuaikan dengan perumusan masalah.

\section{HASIL DAN PEMBAHASAN}

1. Deskripsi Data Hasil Tes Model Terhadap Kemampuan Penalaran Matematis

Berdasarkan hasil penelitian terhadap siswa kelas $\mathrm{VIII}^{3}$ SMP Negeri $2 \mathrm{Na}$.IX-X Sumberjo, didapatkan skor hasil pretest dan posttest kemampuan penalaran matematika siswa yang diperoleh dari masing-masing 5 soal.

\section{a. Deskripsi Hasil Pretest}

\begin{tabular}{|c|c|c|c|}
\hline No & $\begin{array}{c}\text { Interval } \\
\text { Nilai }\end{array}$ & $\begin{array}{c}\text { Frekuensi } \\
\text { Pretest }\end{array}$ & Frekuensi Relatif \\
\hline 1 & $24-27$ & 2 & $7,1 \%$ \\
\hline 2 & $28-31$ & 1 & $3,6 \%$ \\
\hline 3 & $32-35$ & 5 & $17,8 \%$ \\
\hline
\end{tabular}


Hal $21-29$

\begin{tabular}{|l|c|c|c|}
\hline 4 & $36-39$ & 3 & $10,7 \%$ \\
\hline 5 & $40-43$ & 9 & $32.1 \%$ \\
\hline 6 & $44-47$ & 5 & $17.8 \%$ \\
\hline 7 & $48-50$ & 3 & $10,7 \%$ \\
\hline Jumlah & 28 & $100 \%$ \\
\hline Nilai Tertinggi & \multicolumn{2}{|c|}{50} \\
\hline \multicolumn{2}{|c|}{ Nilai Terendah } & \multicolumn{2}{|c|}{39.35} \\
\hline \multicolumn{2}{|c|}{ Mean( rataan ) } & \multicolumn{2}{|c|}{6.424} \\
\hline \multicolumn{2}{|l}{ Standar Deviasi } & \\
\hline
\end{tabular}

Tabel 4.1. Deskripsi Statistika Skor Pretest

b. Deskripsi Hasil Posttest

\begin{tabular}{|c|c|c|c|}
\hline No & Interval Nilai & $\begin{array}{c}\text { Frekuensi } \\
\text { Posttest }\end{array}$ & Frekuensi Relatif \\
\hline 1 & $36-40$ & 2 & $7,1 \%$ \\
\hline 2 & $41-45$ & 2 & $7,1 \%$ \\
\hline 3 & $46-50$ & 2 & $7,1 \%$ \\
\hline 4 & $51-55$ & 0 & $0 \%$ \\
\hline 5 & $56-60$ & 11 & $39.3 \%$ \\
\hline 6 & $61-65$ & 11 & $39.3 \%$ \\
\hline Jumlah & 28 & $100 \%$ \\
\hline Nilai Tertinggi & \multicolumn{2}{|c|}{36} \\
\hline Nilai Terendah & \multicolumn{2}{|c|}{57.21} \\
\hline Mean( rataan ) & \multicolumn{3}{|c|}{8.534} \\
\hline Standar Deviasi & \multicolumn{3}{|c|}{} \\
\hline
\end{tabular}

Tabel 4.2 Deskripsi Statistika Skor Posttest

c. Perbandingan Hasil Pretest dan Posttest

Untuk lebih jelasnya, perbandingan skor pretest dan posttest kemampuan penalaran matematika siswa kelas $\mathrm{VIII}^{3}$ SMP Negeri 2 Na.IX-X Sumberjo

\begin{tabular}{|l|c|c|c|c|}
\hline & $\begin{array}{c}\text { Nilai } \\
\text { Tertinggi }\end{array}$ & $\begin{array}{c}\text { Nilai } \\
\text { Terendah }\end{array}$ & $\begin{array}{c}\text { Mean } \\
\text { (rataan) }\end{array}$ & Standar Deviasi \\
\hline Pretest & 50 & 24 & 39.35 & 6.424 \\
\hline Posttest & 65 & 36 & 57.21 & 8.534 \\
\hline
\end{tabular}

Tabel 4.3 Deskripsi Statistika Skor Pretest dan Posttest

Dari tabel diatas, dapat dilihat nilai tertinggi pretest 50 nilai terendah 24 mean 39,35 dan standar deviasi 6.424. Sedangkan Posttest Nilai tertinggi 65 nilai terendah 36 mean 57,21 dan standar deviasi nya adalah 8.534. Dapat dilihat bahwa setelah diberi perlakuan terdapat peningkatan atau dengan kata lain skor posttest lebih tinggi dibandingkan skor pretest.
Secara umum siswa kelas $\mathrm{VIII}^{3}$ setelah diberi perlakuan mengalami peningkatan. Skor terendah siswa saat pretest adalah 24 , setelah diberi perlakuan skor posttest terendah menjadi 36 . Skor tertinggi pretest siswa adalah 50 , setelah diberi perlakuan skor posttest tertinggi adalah 65. Dibawah ini ditunjukkan diagram batang perbandingan skor pretest dan posttest beberapa siswa : 


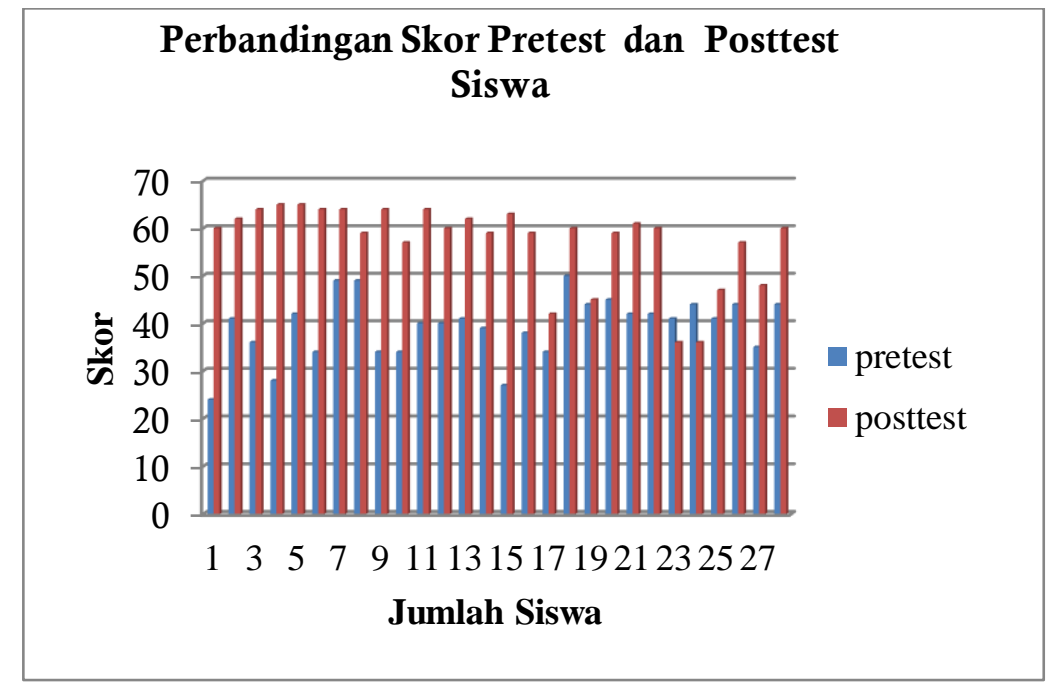

\section{Gambar 4.1. Perbandingan Hasil Pretest dan Posttest}

Grafik diatas menampilkan perbedaan yang diperoleh siswa sebelum dan setelah diberikan perlakuan (treatment). Terlihat jelas bahwa perlakuan (treatment) tersebut mempengaruhi hasil yang siswa peroleh.

\section{d. Deskripsi Analisis Hasil terhadap Angket Respon Siswa}

Berdasarkan hail pengolahan angket diperoleh data bahwa respon siswa terhadap pernyataan butir pertama siswa merasa puas dengan pembelajaran Problem Posing, sebanyak 21 orang $(76,8 \%)$ menjawab sangat setuju. Pernyataan butir kedua model Problem Posing dapat menghilangkan rasa bosan sebanyak 21 siswa $(75,9 \%)$ menjawab sangat setuju. Penyataan butir ketiga model Problem Posing memotivasi siswa untuk belajar sebanyak 24 siswa $(81,3 \%)$ menjawab setuju. Pernyataan butir keempat model Problem Posing membuat siswa rajin belajar sebanyak 22 siswa
(75,9\%) menjawab setuju. Pertanyaan butir lima model Problem Posing membuat siswa aktif belajar sebanyak 24 siswa $(84,8 \%)$ menjawab sangat setuju. Pernyataan butir keenam model Problem Posing membuat siswa mnemahami materi SPLDV sebanyak 22 siswa $(76,8 \%)$ menjawab sangat sangat setuju. Pernyatan butir ketujuh model Problem Posing siswa semangat mempelajari materi SPLDV sebanyak 26 siswa $(83,9 \%)$ menjawab sangat setuju. Pernyataan butir kedelapan model pembelajaran Problem Posing membuat keingin tahuan siswa besar terhadap materi SPLDV sebanyak 22 siswa (76,8\%) menjawab sangat setuju. Pernyataan butir kesembilan model pembelajaran Problem Posing sangat cocok diterapkan dimateri SPLDV sebanyak 22 siswa $(80,4 \%)$ menjawab sangat setuju.pernyataan butir kesepuluh model pembelajaran Problem Posing membuat siswa bersungguh-sungguh mempelajari materi SPLDV sebanyak 21 siswa $(76,8 \%)$ menjawab sangat setuju. 


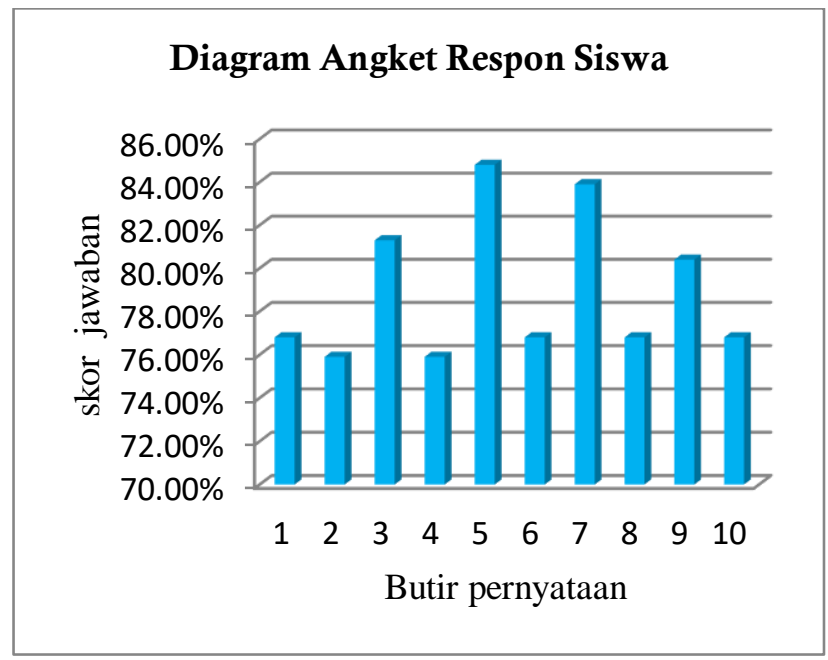

\section{Gambar 4.2. Rekapitulasi Diagram Angket Respon Siswa}

Berdasarkan hasil data diatas dapat disimpulkan bahwa respon siswa terhadap minat belajar dengan model pembelajaran Problem Posing apabila diratakan adalah $78,93(70,5 \%)$ dalam katagori setuju.hal ini menunjukan respon siswa terhdap model pembelajaran Problem Posing tergolong baik terutama pada materi sistem persamaaan linear dua variable

\section{Teknik Analisis Data}

Setelah data hasil penelitian didapat, maka data akan dianalisis. Sebelum melakukan analisis, terlebih dahulu dilakukan pengujian prasyarat analisis data, yaitu uji normalitas dan uji homogenitas, guna mengetahui apakah data yang diperoleh terdistribusi normal atau tidak dan untuk mengetahui apakah kedua data tersebut homogen ataun tidak.

\section{Uji Normalitas}

Dalam penelitian ini, Untuk perhitungan uji normalitas manual dengan menggunakan uji chi-kuadrat $\left(\chi^{2}\right)$ dengan pengambilan keputusan jika $\chi^{2}{ }_{\text {nitung }}<$ $\chi_{\text {tabel }}^{2}$ maka data berdistribusi normal. Hasil uji normalitas pretest dan posttest dapat dilihat pada tabel berikut :

\section{Tabel 4.4 Hasil Uji Normalitas Pretest dan Posttest}

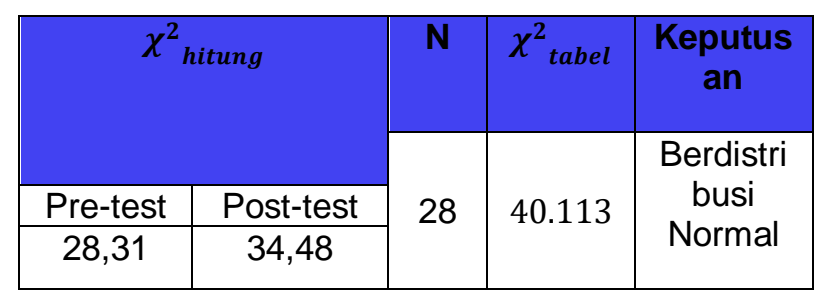

Berdasarkan tabel 4.4 skor pretest dan skor posttest tersebut berdistribusi normal.

\section{Uji Homogenitas}

Uji homogenitas dilakukan dengan cara manual. Untuk perhitungan uji homogenitas manual dengan menggunakan uji $\mathrm{F}$ dengan pengambilan keputusan jika $F_{\text {hitung }}<F_{\text {tabel }}$ maka data homogen.

Berikut ini disajikan rangkuman hasil perhitungan uji homogenitas seperti pada tabel 4.6 berikut ini: 
Tabel 4.5 Hasil Pengujian Homogenitas

\begin{tabular}{|c|c|c|c|}
\hline$F_{\text {hitung }}$ & $F_{\text {tabel }}$ & $\mathbf{N}$ & Keputusan \\
\hline 1,77 & 1,90 & 28 & Homogen \\
\hline $\begin{array}{l}\text { Terlihat pada tabel diatas bahv } \\
F_{\text {tabel }} \text { yaitu } 1,77<1,90 \text { maka } \\
\text { homogen. }\end{array}$ & $\begin{array}{rr}\text { va } & F_{\text {hitung }}< \\
\text { data }\end{array}$ & $\begin{array}{l}\text { normal. } \\
\text { perlakuan (tre } \\
\text { memberikan has } \\
\text { nyata atau t } \\
\text { pengujian hipotes }\end{array}$ & $\begin{array}{l}\text { Untuk menguji apakah } \\
\text { atment) pada sampel } \\
\text { sil yang berbeda secara } \\
\text { dak, maka digunakan } \\
\text { sis Paired Samples T-Test. }\end{array}$ \\
\hline $\begin{array}{l}\text { Uji Hipotesis } \\
\text { Setelah dilakukan } \\
\text { prasyarat analisis, maka }\end{array}$ & $\begin{array}{r}\text { pengujian } \\
\text { selanjutnya }\end{array}$ & $\begin{array}{l}\text { Berikut adalah } \mathrm{t} \\
\text { pretest dan } p \\
\text { Paired Samples }\end{array}$ & $\begin{array}{l}\text { bel hasil uji hipotesis da } \\
\text { sttest menggunakan } \\
\text {-Test. }\end{array}$ \\
\hline
\end{tabular}
dilakukan pengujian hipotesis. Pengujian hipotesis dilakukan dengan statistik parametrik karena data berdistribusi

\section{Tabel 4.6 Hasil Uji Hipotesis Data Pretest dan Posttest}

\begin{tabular}{|c|c|c|c|c|}
\hline Data & $\mathbf{N}$ & $t_{\text {hitung }}$ & $\mathbf{t}_{\text {tabel }}$ & Keputusan \\
\hline $\begin{array}{c}\text { Pretest } \\
\text { dan } \\
\text { Posttest }\end{array}$ & 28 & 10.308 & 2,048 & Ho ditolak \\
\hline
\end{tabular}

Berdasarkan tabel 4.7 diatas, terlihat bahwa nilai uji pre-test dan post test diperoleh nilai thitung $>t_{\text {tabel }}$ yaitu $10.308>$ 2,048 berarti ada perbedaan yang signifikan pengukuran data pretest dan posttest. Maka $\mathrm{H}_{\mathrm{a}}$ diterima dan dapat disimpulkan bahwa terdapat pengaruh model pembelajaran Problem Posing terhadap kemampuan penalaran matematika siswa pada materi Sistem Persamaan Linear Dua Variabel (SPLDV).

Berdasarkan hasil pengolahan data yang telah diuraikan sebelumnya, skor sebelum diberi perlakuan dan skor setelah diberi perlakuan terdapat perbedaan. Hal ini terlihat dari hasil pengujian hipotesis dengan uji Paired Samples T-Test untuk sampel yang berdistribusi normal diperoleh nilai $2,048<10.308$ maka $\mathrm{H}_{0}$ ditolak dan $\mathrm{H}_{\mathrm{a}}$ diterima dengan kata lain terdapat pengaruh Model Pembelajaran Problem Posing Terhadap Kemampuan Penalaran matematis siswa pada materi Sistem Persamaan Linear Dua Variabel (SPLDV).

Selain dilihat dari uji hipotesis, pengaruh kemampuan penalaran matematika siswa juga dapat dilihat dari skor terendah siswa saat pretest adalah 24, setelah diberi perlakuan skor posttest terendah menjadi 36. Skor tertinggi pretest siswa adalah 50 , setelah diberi perlakuan skor posttest tertinggi adalah 65. Maka disimpulkan bahwa setelah diberi perlakuan terdapat peningkatan atau dengan kata lain skor posttest lebih tinggi dibandingkan skor pretest. Berarti Model Pembelajaran Problem Posing mempengaruhi kemampuan penalaran matematis siswa. Dengan demikian penelitian "Pengaruh Model Pembelajaran Problem Posing mempengaruhi kemampuan penalaran matematis siswa pada materi Sistem Persamaan Linear Dua Variabel (SPLDV)" mampu menjawab hipotesis yang diajukan melalui analisis data-data yang diperoleh yaitu penelitian membuktikan bahwa terdapat pengaruh Model Pembelajaran Problem Posing mempengaruhi kemampuan penalaran matematis siswa.

Berdasarkan hasil data angket respon siswa dapat disimpulkan bahwa respon siswa terhadap minat belajar dengan model pembelajaran Problem Posing jika di jumlahkan hasil nya adalah $884(789,3 \%)$ dan apabila diratakan adalah 78,93 (70,5\%) dalam katagori setuju.hal ini menunjukan respon siswa terhadap model pembelajaran Problem Posing tergolong baik terutama pada materi sistem persamaaan linear dua variable. 


\section{KESIMPULAN DAN SARAN Kesimpulan}

Berdasarkan hasil pengolahan dan analisis data yang diperoleh dari penelitian yang telah dilakukan di SMP Negeri $2 \mathrm{Na}$. IX-X sumberjo yang berlokasi di desa sei raja, dusun sumberjo, kecamatan $\mathrm{Na}$. IX-X, kabupaten labuhanbatu utara, maka dapat ditarik kesimpulan sebagai berikut :

1. Terdapat pengaruh Model Pembelajaran Problem Posing terhadap kemampuan penalaran matematika siswa pada materi Sistem Persamaan Linear Dua Variabel (SPLDV). Hal ini dapat dibuktikan dari skor terendah siswa saat pretest adalah 24, setelah diberi perlakuan skor posttest terendah menjadi 36 . Skor tertinggi pretest siswa adalah 50, setelah diberi perlakuan skor posttest tertinggi adalah 65. Demikian juga berdasarkan uji Paired Samples TTest diperoleh nilai Sehingga nilai thitung > tabel yaitu $10.308>2,048$ maka $\mathrm{H}_{0}$ ditolak dan $\mathrm{H}_{\mathrm{a}}$ diterima.

2. Berdasarkan hasil pengolahan angket respon siswa dengan mengunakan Skala Liket diperoleh bahwa respon siswa terhadap model pembelajaran Problem Posing. Pada materi SPLDV sebesar 78,93 (70,5 \%) dalam katagori setuju. Hal ini dapat di artikan respon siswa cendrung baik terhadap penggunaan model Problem Posing pada materi SPLDV.

\section{Saran}

Berdasarkan hasil penelitian dan kesimpulan yang diperoleh oleh peneliti dalam menggunakan model pembelajaran problem posing ini, peneliti mengajukan beberapa saran yang dapat dijadikan pertimbangan, yaitu:

1. Guru hendaknya menanamkan pada siswa bahwa pembelajaran matematika bermakna dalam kehidupan sehari-hari, sehingga siswa sendiri akan mencari dan menyukai pelajaran matematika, guru juga dapat menggunakan model pembelajaran problem posing sebagai alternative model pembelajaran terutama pada materi SPLDV, karena dengan mengunakan model pembelajaran problem posing dapat dapat membimbing siswa untuk lebih aktif dalam proses pembelajaran

2. Bagi Siswa Hendaklah memperhatikan apa yang di ajarkan oleh guru dan menanyakan hal-hal yang belum di mengerti sehingga di peroleh pembelajaran yang jelas dan mudah dipahami oleh siswa.

3. Bagi peneliti selanjutnya, perlu dilakukan peneliti mengenai model pembelajaran problem posing dengan kemampuan yang berbeda serta dapat dilakukan di lokasi yang berbeda Pembelajaran dengan model Problem Posing perlu juga diterapkan dan dikembangkan pada materi lain agar siswa lebih memahami materi yang dipelajari yaitu yang berhubungan dan berguna bagi kehidupan sehari-hari. 


\section{DAFTAR PUSTAKA}

Ainun, Nur. 2015. Peningkatan Kemampuan Penalaran Matematis Siswa Madrasah Aliyah Melalui Model Pembelajaran Kooperatif Tipe Teams Games Tournament. Program Studi Pendidikan Matematika Universitas Serambi Mekkah, Banda Aceh. (Jurnal Peluang, Volume 4, Nomor 1, Oktober 2015)

Wulandari, Enika 2012. "Meningkatkan Kemampuan Penalaran Matematis Siswa Melalui Pendekatan Problem Posing di Kelas VIII A SMP Negeri 2 Yogyakarta Tahun Ajaran 2012/2013. Program Studi Pendidikan Matematika jurusan Matematika dan IImu Pengetahuan Alam Universitas Negeri Yogyakarta.

Puspita , Lilik (2013). “Model Pembelajaran Problem Posing Terhadap Hasil Belajar Matematika Materi Himpunan Pada Siswa Kelas VII Negeri 2 Kampak Trenggalek Semester Genap Tahun Pelajaran 2013/2014. program studi Matematika jurusan Tarbiyah IAIN Tulungagung,

Efendi, M. Yusuf. (2014). Upaya Peningkatan Kemampuan Pemahaman Konsep dan Penalaran Matematika Siswa pada Pokok Bahasan Peluang Dengan Menggunakan Model Pembelajaran berbasis Masalah di SMA Negeri 2 Binjai. Tesis. Medan: UNIMED Pendidikan Matematika.

Purnamasari. 2014. Pengaruh Model Pembelajaran Problem Posing Terhadap Hasil Belajar Matematika Materi Himpunan Pada Siswa Kelas VII SMP Negeri 2 Kampak Trenggalek. IAIN Tulungagung.

Udhayani, Lovia (2014). Penerapan Strategi Pembelajaran Problem Based Learning Untuk Meningkatkan Kemampuan Penalaran Matematika Siswa Tahun Pelajaran 2014/2015. program studi matematika Fakultas
Keguruan dan IImu Pendidikan Universitas Muhamadiyah 2014.

Susiana. $2011 \quad$.Pengembangan Kemampuan Penalaran Matematis Mahasiswa pada Mata Kuliah Persamaan Diferensial. Mahasiswa

Matematika. Jurnal Kreano ISSN Vol.5 no 1,2011 .

Priatna, Ainin Ditya Hilmi.2013. Peningkatan Kemampuan Berpikir Kritis dan Penalaran Siswa Pada Matematika Dengan Model Pembelajaran Problem Posing. Universitas muhamadiyah Surakarta.

Utami, Nita Putri . Kemampuan Penalaran Matematis Siswa Kelas XI IPA SMAN 2 Painan Melalui Penerapan Pembelajaran Think Pair Square. ( Jurnal Pendidikan Matematika 2014) Vol 3 No 1.

Siregar, Syofian.2011. Statistik Deskriptif untuk Penelitian. JakartaRajawali Pers.

Priatna, 2013 Kemampuan penalaran matematis Siswa Pada Matematika Dengan Model Pembelajaran Problem Posing. Universitas Indonesia.

Sudjana 2005. Dasar-dasar Evaluasi Pendidikan. Jakarta: Bumi Aksara.

Sugiyono. 2008. Metode Penelitian Pendidikan Pendekatan Kuantitatif, Kualitatif, dan R\&D. Bandung: Alfabeta 